\title{
Poverty, Poaching and Trafficking: What are the links?
}

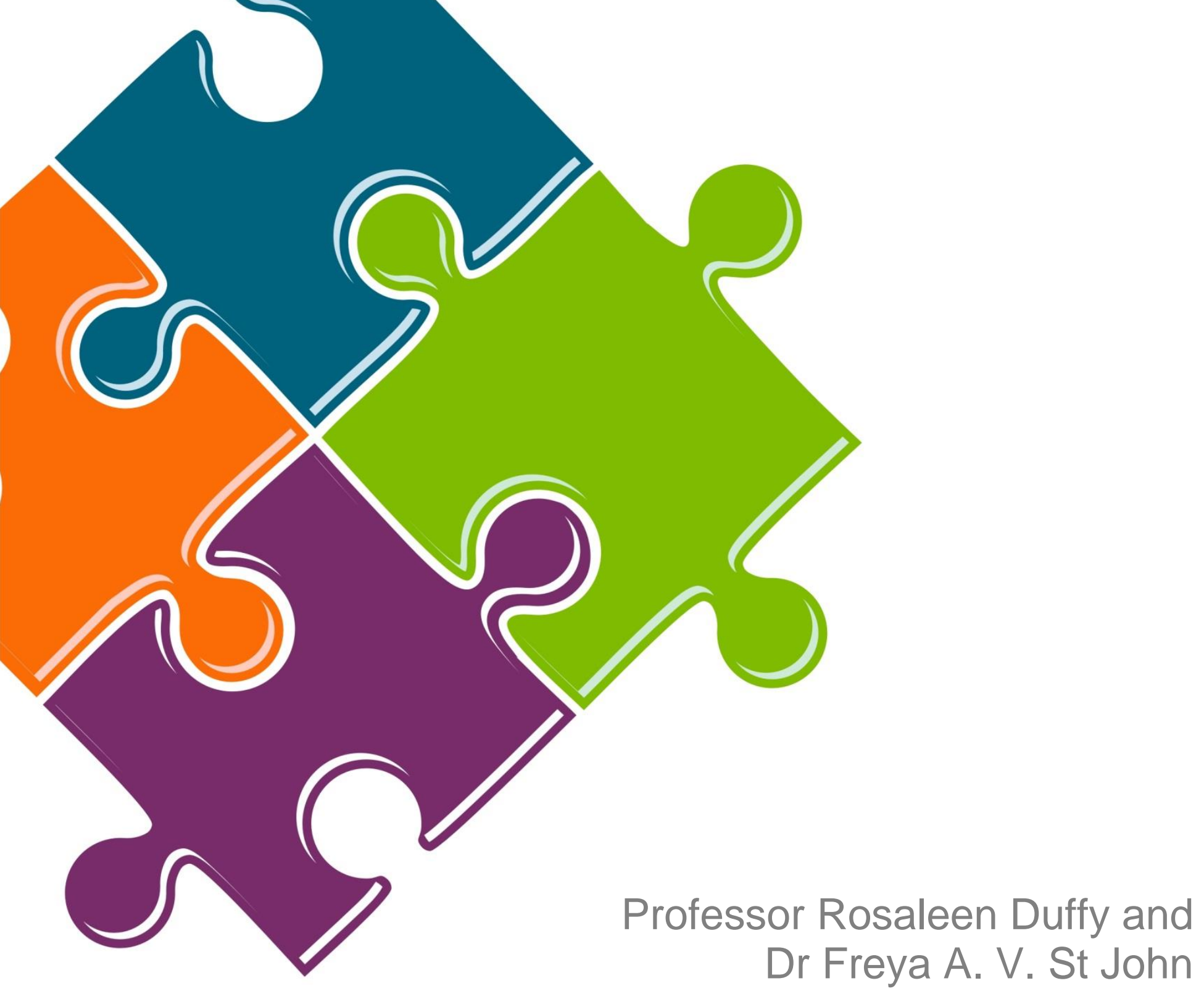

June 2013
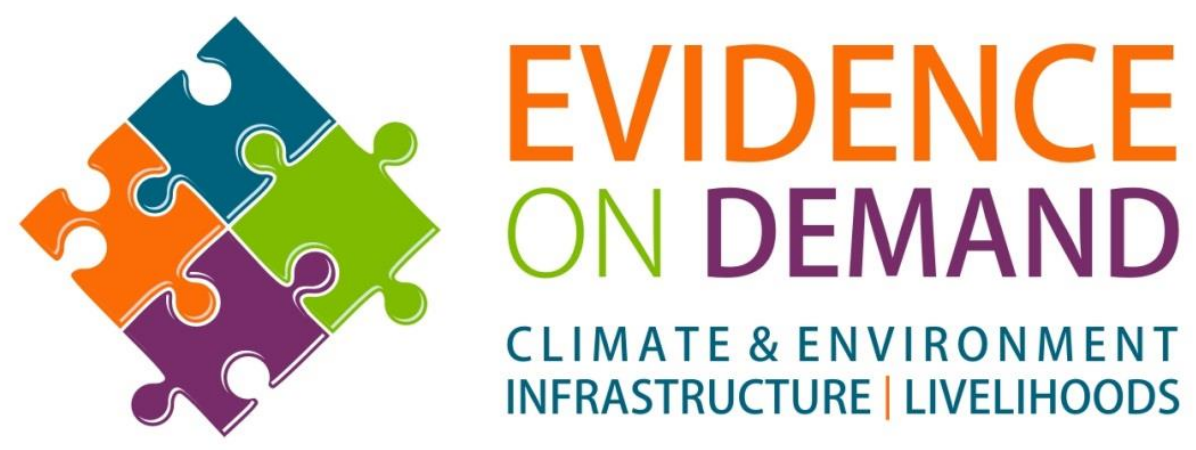

CLIMATE \& ENVIRONMENT INFRASTRUCTURE | LIVELIHOODS 


\section{Contents}

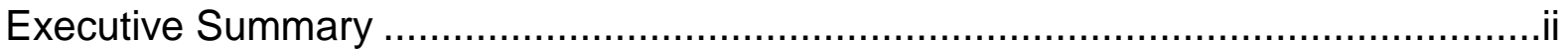

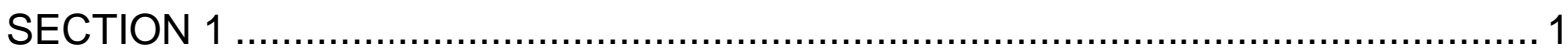

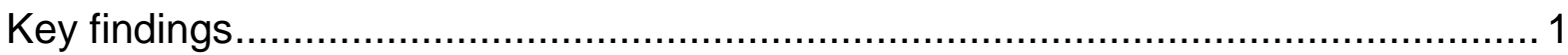

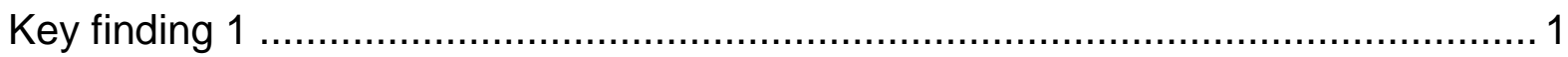

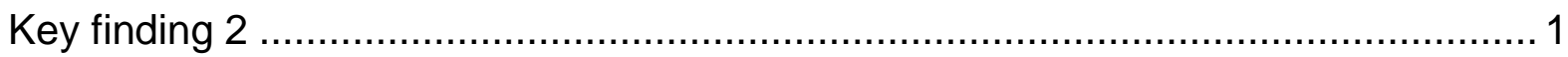

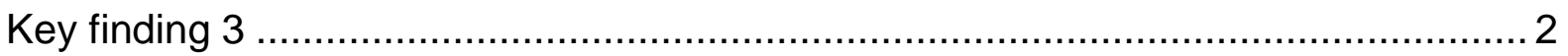

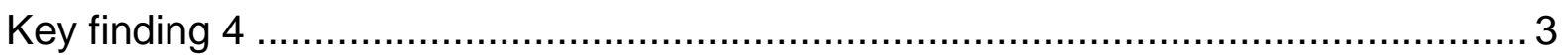

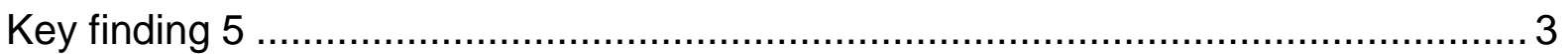

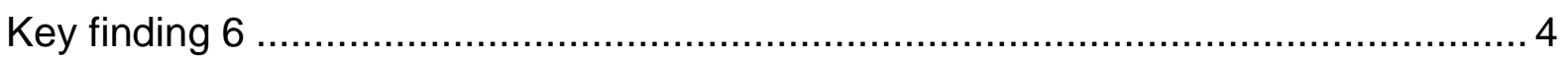

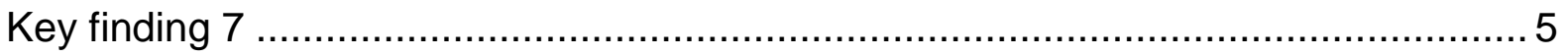

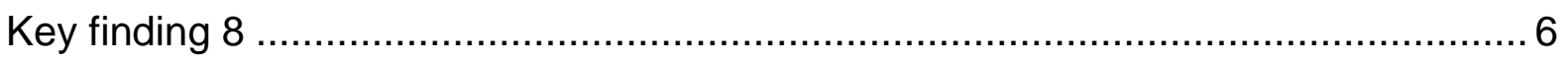

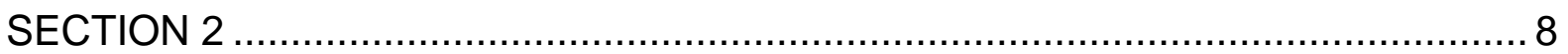

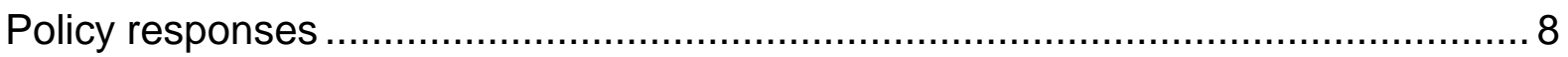

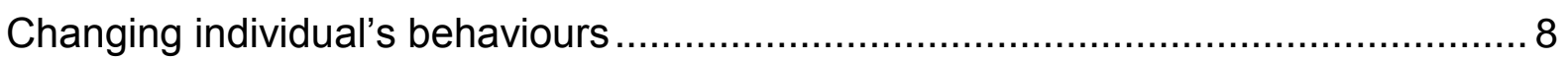

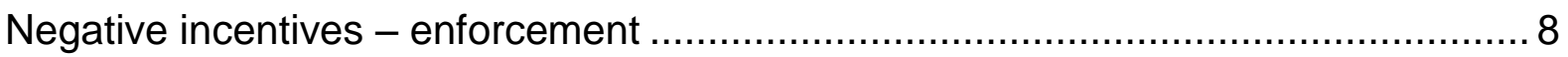

Positive incentives - integrating local people into the management of natural

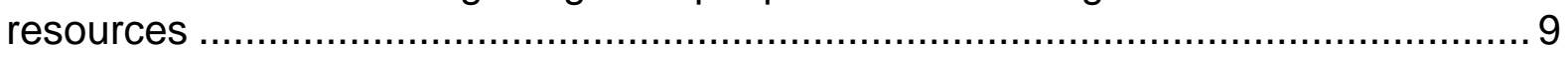

Distractions - offering alternatives to illegal poaching .................................... 10

Tourism as a route to poverty reduction ................................................... 10

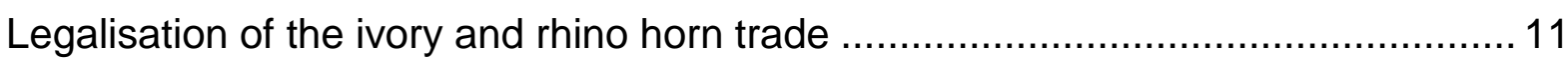

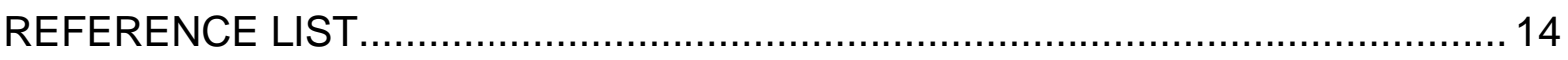

\section{List of Case Studies}

Case Studies 1 Luangwa Valley, Zambia ................................................................. 12

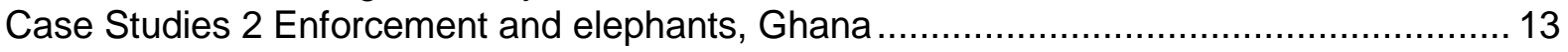

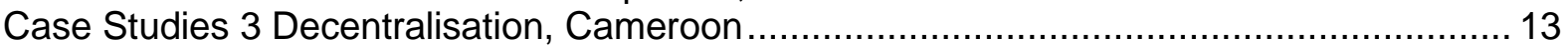




\section{Executive Summary}

Our rapid review of the academic and grey literature revealed that the links between poverty, poaching and trafficking are under-researched and poorly understood. Yet, the assumption that poaching occurs because of poverty is omnipresent, with little 'hard evidence' to support the claim. Despite this, we are confident that the links are there, based on the evidence that we gathered. However, our understandings are hampered by a series of factors: trafficking and poaching are overwhelmingly framed as an issue of conservation/biodiversity loss rather than of poverty and development; it is difficult to collect clear and detailed data on poaching precisely because of its illicit nature; and many of the cases we examined are also linked in with conflict zones, making research even more challenging. Nevertheless, our key findings are as follows:

1. Poaching in Sub Saharan African was produced via the historical legacy of colonialism

2. Poverty is directly and indirectly linked to poaching and trafficking of ivory and rhino horn from Sub-Saharan Africa

3. There are different types of poachers, and they require different policy responses

4. Poaching and trafficking of ivory and rhino horn are ultimately driven by wealth and not by poverty per se.

5. We need a much better understanding of the relationships between poverty and individual poacher motivation

6. The evidence base for claims around poverty as a driver of ivory and rhino poaching is thin, but that does not mean that poverty is not an important factor

7. There are direct links between conflict zones, illegal killing of wildlife, trafficking and poverty.

8. Trafficking can increase poverty

We then summarise the main policy responses, identifying their strengths and weaknesses. These include:

1. Changing people's behaviour via negative incentives (e.g. monitoring compliance with rules and penalising detected rule breakers), positive incentives and distractions.

2. The development of tourism as a route to poverty reduction.

3. Legalisation of the ivory and rhino horn trade at the international level, including arguments around its potential impact on community based natural resource management schemes.

Finally, we offer a series of short case studies that indicate these complex linkages via an analysis of particular examples. 


\section{SECTION 1 \\ Key findings}

\section{Key finding 1}

\section{Poaching in Sub Saharan Africa was produced via the historical legacy of colonialism}

One of the legacies of colonialism was that legal rights to hunt were removed from Africans in order to protect sport hunting and the safari industry for European colonisers (Adams 2004; Jacoby, 2003; Neumann, 2004). This process of enclosure removed rights to subsistence hunting and further impoverished African communities. This also partly explains why some communities in Sub-Saharan Africa continue to resist and ignore legislation protecting wildlife because they believe they have a right to access and use wildlife as they have done for generations (Duffy, 2010; Neuman, 2001; Carruthers, 1995; Robbins et al. 2009; Bolaane, 2004; Mackenzie, 1988; Norgrove and Hulme, 2006; Adams 2004: 19-24; Roe, 2008b; Garland, 2008; Neumann, 1998; Fischer et al. 2013).

\section{Key finding 2}

\section{Poverty is directly and indirectly linked to poaching and trafficking of ivory and rhino horn from Sub-Saharan Africa}

This set of issues squarely fits under Millennium Development Goal 7, Ensure Environmental Sustainability. The UN states that MDG7 can be achieved via a series of targets, one of which is target $7 \mathrm{~b}$ : reduce biodiversity loss, achieving by 2010 , a significant reduction in the rate of loss ${ }^{1}$ (also see Roe et al. 2011; Roe and Elliot (eds) 2010).

In order to respond effectively to the links between poverty, trafficking and poaching in SubSaharan Africa, we need to understand how it developed. There is no easy link between poverty and trafficking. Adams et al. (2004) distinguished four key arguments in the conservation-poverty debate:

(a) Conservation and poverty are separate policy realms

(b) Conservation should not compromise poverty reduction

(c) Poverty impedes conservation because poaching and environmental degradation is often pursued by the poor in short-sighted ways. When people become richer they are more amenable to accepting conservation policies. Addressing poverty is therefore a means of directly and indirectly promoting conservation.

(d) Poverty reduction depends on sustainable resource use. Where livelihoods depend on living resources their sustainable use will promote both the resource and the livelihood associated with it.

In order to achieve MDG 7, it is important to explore further the links between wildlife trafficking, poaching and poverty. It is useful to note one of the Key Performance Indicators of MDG 7 is setting aside $10 \%$ of land as protected area, which reveals the centrality and importance of such models of conservation. Wildlife conservationists and development 


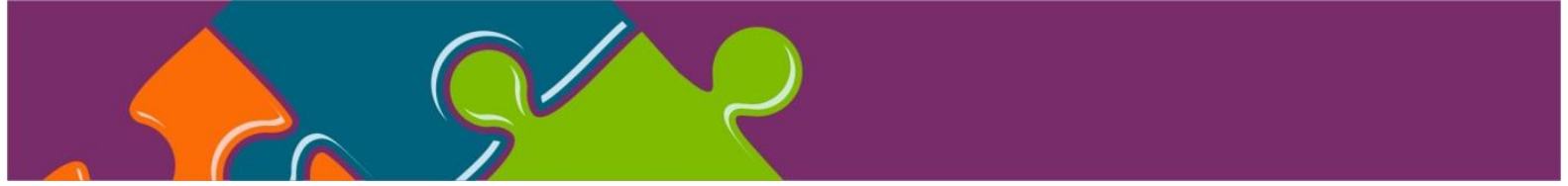

Little attention has been given to studying the drivers of illegal natural resource extraction by gathering data directly from the public, which includes potential rule-breakers. This is largely due to the difficulties associated with studying illegal activities, with rule breakers unwilling to identify themselves for fear of punishment (Gavin et al. 2010; St. John et al. 2010).

In the only study of its kind to date, Burn et al. (2011) explore country level drivers and spatial distribution of elephant poaching using data from the database Monitoring the Illegal Killing of Elephants (MIKE) set up by the $10^{\text {th }}$ CoP of CITES in 1997. MIKE holds site-level carcass encounter data reported mainly through anti-poaching patrols. Data analysed were site by year totals of 6,337 carcasses from 66 MIKE sites in 36 range states in Africa and Asia between 2002 and 2009. Results indicate that sites with forest cover, such as those within Central Africa, experience higher levels of poaching than savannah sites, presumably because detection by enforcement officials is less likely in such habitats so poachers have greater freedom of movement Burn et al. (2011). However, it may be that states with forests have weaker enforcement capacity. At the country level, drivers of illegal killing that emerged from the analysis were poor governance and low levels of human development (Burn et al. 2011). Stiles (2011) reported that the main reasons for elephant poaching given by those who participate in hunting were lack of law enforcement and poverty. Similar findings have been reported by others for African elephants and black rhinoceroses (Smith et al. 2003). Burn et al. (2011) highlight the fact that:

'...we [the authors] are only just beginning to make inroads into understanding the plethora of potential impacts - social, political, economic and ecological, and the causal pathways between them - on elephant poaching and illicit ivory trade' (Burn et al. 2011).

\section{Key finding 7}

\section{There are direct links between conflict zones, illegal killing of wildlife, trafficking and poverty}

Poorer communities in conflict areas lose the value of wildlife to organised militia and rebel groups who use ivory and rhino horn to fund their operations. Furthermore, it prevents the development of tourism because tourists are put off by the risks associated with a combination of conflict zones and poaching. Tourism is difficult to develop in areas of ongoing conflict because of the risks to international tourists and the lack of facilities. This is a major challenge for communities aiming to capture tourist value of wildlife in CAR, Sudan, DRC and the Rwanda-Uganda-DRC border areas (Lombard, 2012). The rise in poaching in Central African Republic and its relationships to regional security issues (Chad, Cameroon, CAR and Gabon) was detailed in a report by UN Secretary General, Ban Ki Moon (UN, 2013). Zakouma National Park in Chad has also suffered poaching by rebel groups to fund cross border wars; Garamba National Park (DRC) was used as a base by the Lord's Resistance Army (LRA) in 2012 and it used ivory poaching to underpin and finance operations; leader of the LRA, Joseph Kony, was based there in 2012 (UN, 2013). ${ }^{3}$ However, the claim that new ivory wars are organised by Janjaweed militia and LRA has been seriously questioned - Lombard suggests these are simplistic and 'easy labels' used by Governments in the region to entice in external help or to demonise poachers as

http://www.african-parks.org/; $\quad$ http://www.cnn.com/2013/06/05/world/africa/kony-elephantpoaching; Christy, B. 'Blood Ivory' National Geographic, October 2012; Keith Somerville, African Arguments Series (Royal African Society) Ivory Wars: How Poaching in Central Africa Fuels the LRA and Janjaweed, 14.01.13, http://africanarguments.org/2013/01/14/the-ivorywars-how-poaching-in-central-africa-fuels-the-Ira-and-janjaweed-\%E2\%80\%93-by-keithsomerville/ 


\section{SECTION 2 \\ Policy responses}

\section{Changing individual's behaviours}

Interventions typically combine approaches from three broad categories (St. John et al. 2013):

Negative incentives: typically enforcement designed to deter illegal activities such as poaching, but also includes campaigns to alter public opinion making activities socially costly (e.g. campaigns against fur).

Positive incentives: money or benefits in kind are given to communities or individuals for behaving in a certain way, e.g. refraining from illegal resource extraction.

Distractions: alternative options, for example improved crop yields, are offered to reduce the comparative attractiveness of illegal activities.

\section{Negative incentives - enforcement}

Evidence indicates that reducing effort devoted to enforcement within protected areas leads to increased levels of poaching. Fifty years of records from Serengeti, Tanzania show that the rapid decline in enforcement in 1977 resulted in large increases in poaching and the decline of many species. From the mid-1980s expanded budgets allowed for increased antipoaching patrols, as a result, poaching was greatly reduced and populations of buffalo, elephants, and rhinoceros showed signs of recovery (Hilborn et al. 2006).

Enforcement is financially costly, consequently enforcement at a levels adequate to protect elephant and rhino are prohibitively expensive for most African range States. Techniques for optimising enforcement strategies are therefore required. To this end, studies from Luangwa Valley, Zambia model the influence of sentencing structure on poacher decision-making and how anti-poaching resource allocation relates to poaching rates (Case Study 1, Zambia). Further, evidence from Ghana (Case Study 2, Ghana) indicates that market raids (Martin 2010) and monitoring enforcement-staff performance can contribute to reduced poaching as a result of improved staff performance (Jachmann 2008b).

However, enforcement is not only financially costly it can also be costly in terms of local relations. Enforcement can erode trust between conservation authorities and local people by restricting access to resources that have an irreplaceable role in the lives of local people (Infield 2001). Indeed, evidence indicates that trust and legitimacy between protected area staff and local people are key factors related to voluntary compliance where general agreement with regulations does not necessarily exist (Stern 2008).

Increased levels of military-style enforcement could increase poverty and alienate local communities. An increasingly common response is to suggest the need for greater levels of enforcement; this goes beyond more traditional understandings of negative incentives designed to encourage individuals not to engage in illegal behaviours via use of fines, imprisonment and public awareness campaigns (Terborgh, 1999; Oates, 1999; Hutton, Adams and Murombedzi, 2005; Leakey, 2001); even UN Secretary General Ban Ki Moon 


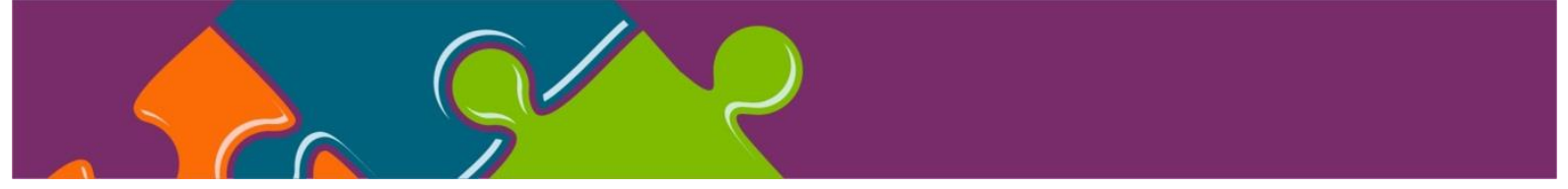

\section{REFERENCE LIST}

Abernsperg-Traun, M., C. O'Criodain and D. Roe (eds) (2011) CITES and CBNRM: Proceedings of an international symposium on "The relevance of CBNRM to the conservation and sustainable use of CITES-listed species in exporting countries" (London: IIED)

Adams, J. S. and McShane, T. O. (1992) The Myth of Wild Africa: Conservation Without Illusion (Berkeley, CA: University of California Press)

Adams, W.M. (2009) 'Sportsman's shot, poacher's pot: hunting, local people and the history of conservation' in Dickson, B., J. Hutton and Adams, W.M. (eds) Recreational Hunting, Conservation and Rural Livelihoods: Science and Practice (Chichester: John Wiley and Sons) pp. 127-140.

Adams, W. M. (2004) Against Extinction: The Story of Conservation (London: Earthscan)

Adams, W. M. and Infield, M. (2003) 'Who is on the gorilla's payroll? Claims on tourist revenue from a Ugandan National Park', World Development, 31(1): 177-90

Adams, W. M. et al. (2004) 'Biodiversity conservation and the eradication of poverty?', Science, 306: 1146-9

Agrawal, A. (2001) Common property institutions and sustainable governance of resources. World Development 29 (10): 1649-72.

Agrawal, A. and Gibson, C. C. (1999) 'Enchantment and disenchantment: The role of community in natural resource conservation', World Development, 27(4): 629-4

Ashley, C., D. Roe and H. Goodwin (2001) Pro-Poor Tourism Strategies: Making Tourism Work For The Poor - A review of experience (London: ODI).

Ajzen, I. (1991) The theory of planned behavior. Organizational Behavior and Human Decision Processes 50, 179-211.

Ajzen, I., Fishbein, M., (1980) Understanding attitudes and predicting social behaviour. Prentice-Hall, Englewood Cliffs, New Jersey 07632.

Alvard, M.S., et al. (1997) The sustainability of subsistence hunting in the neotropics. Conservation Biology 11(4):977-82.

Barrett, C., B., Arcese, P. (1995) Are Integrated Conservation-Development Projects (ICDPs) sustainable? On the conservation of large mammals in sub-Saharan Africa. World Development 23, 1073-1084.

Barrett, C.B., Arcese, P., (1998) Wildlife harvest in integrated conservation and development projects: linking harvest to household demand, agricultural production, and environmental shocks in the Serengeti. Land Economics 74, 449-465.

Barrow, E. and Fabricius, C. (2002) 'Do rural people really benefit from protected areas rhetoric or reality?', Parks, 12: 67-79

Becker, M., McRobb, R., Watson, F., Droge, E., Kanyembo, B., Murdoch, J., Kakumbi, C., (2013) Evaluating wire-snare poaching trends and the impacts of by-catch on elephants and large carnivores. Biological Conservation 158, 26-36.

Benz, S. and J. Benz-Schwarzburg (2011) 'Great Apes And New Wars' Civil Wars 12(4): 395-430

Bodmer, R.E., and E.P. Lozano (2001) Rural Development and Sustainable Wildlife Use in Peru. Conservation Biology 15(4):1163-1170.

Bolaane, M. (2004) 'The impact of game reserve policy on the River BaSarwa/Bushmen of Botswana', Social Policy and Administration, 38(4): 399-417

Bonner, R. (1993) At the Hand of Man: Peril and Hope for Africa's Wildlife (London: Simon and Schuster)

Borgerhoff-Mulder, M. and Coppolillo, P. (2005) Conservation: Linking Ecology, Economics, and Culture (Princeton, NJ: Princeton University Press). 


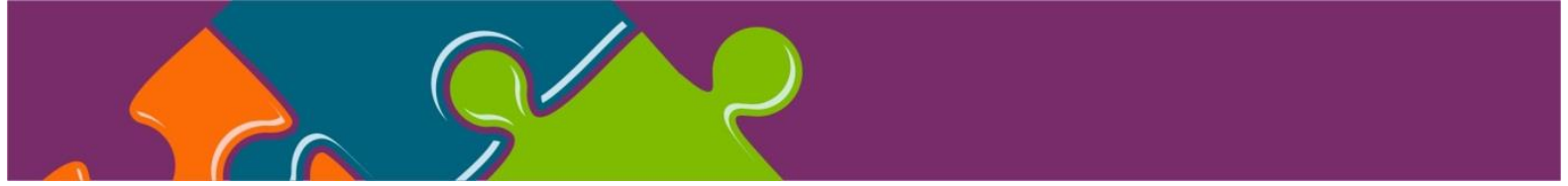

Honey, M. (1999) Ecotourism and Sustainable Development. Who Owns Paradise? (Washington D.C.: Island Press).

Hounsome, B., Edwards, R.T., Edwards-Jones, G., (2006) A note on the effect of farmer mental health on adoption: The case of agri-environment schemes. Agricultural Systems 91, 229-241.

Hughes, R., Flintan, F., (2001) Integrating Conservation and Development Experience: A Review and Bibliography of the ICDP Literature, In Biodiversity and Livelihoods Issues No.3. International Institute for Environment and Development. London, Citation: Hughes, R. and Flintan, F. (2001).

Hulme, D. and Murphee, M. (eds) (2001) African Wildlife and Livelihoods: The Promise and Performance of Community Conservation (Oxford: James Currey)

Humphreys, J. and M.L.R. Smith (2011) 'War and Wildlife: The Clausewitz Connection' International Affairs 87 (1): 121-142

Hutton, J. and Dickson, B. (2000) Endangered Species, Threatened Convention: The Past Present and Future of CITES (London: Earthscan)

Hutton, J., Adams, W. M. and Murombedzi, J. C. (2005) 'Back to the barriers? Changing narratives in biodiversity conservation', Forum for Development Studies, 32(2): 341-70

IFAW (2008) Killing with Keystrokes: An Investigation of the Illegal Wildlife Trade on the World Wide Web (Brussels: IFAW)

Infield, M., (2001) Cultural Values: A Forgotten Strategy for Building Community Support for Protected Areas in Africa. Conservation Biology 15, 800-802.

Infield, M., Namara, A., (2001) Community attitudes and behaviour towards conservation: an assessment of a community conservation programme around Lake Mburo National Park, Uganda. Oryx 35, 48-60.

IUCN (1980) The International Trade in Rhinoceros Products, report prepared by E. B. Martin for IUCN and WWF (Gland, Switzerland: IUCN/WWF)

IUCN (1992) Analysis of Proposals to Amend the CITES Appendices, prepared by the IUCN Species Survival Commission Trade Specialist Group, TRAFFIC and WCMC for the 8th Meeting of the Conference of the Parties, Kyoto Japan 2-13 March 1992 (Gland, Switzerland: IUCN)

Ivory Trade Review Group (1989) The Ivory Trade and the Future of the African Elephant, vol. 1 (summary and conclusions), report prepared for the 7th CITES, Conference of the Parties, Lausanne, October 1989 (Oxford: ITRG)

Jacoby, K. (2003) Crimes Against Nature Squatters, Poachers, Thieves, \& the Hidden History of American Conservation (Berkeley, CA: University of California Press)

Jachmann, H., (2008a) Illegal wildlife use and protected area management in Ghana. Biological Conservation 141, 1906-1918.

Jachmann, H., (2008b) Monitoring law-enforcement performance in nine protected areas in Ghana. Biological Conservation 141, 89-99.

Jachmann, H., Billiouw, M., (1997) Elephant poaching and law enforcement in the central Luangwa Valley, Zambia. Journal of Applied Ecology 34, 233-244.

Jambiya, J., S. Milledge and N. Mtango (2007) Night Time Spinach: Conservation and Livelihood Implications of Wild Meat Use in Refugee Situations in North-Western Tanzania (Dar Es Salaam: TRAFFIC East-Southern Africa)

Janssen, M.A., R. Holahan, A. Lee and E. Ostrom (2010) Lab Experiments for the Study of Social-Ecological Systems. Science, 328(5978): 613-617.

Johannes, R.E., (1978) Traditional marine conservation methods in Oceania and their demise. Annual Review of Ecology and Systematics 9, 349-364.

Johannesen, A.B., (2006) Designing integrated conservation and development projects (ICDPs): illegal hunting, wildlife conservation, and the welfare of the local people. Environment and Development Economics 11, 247-267.

Jones, J.P.G., Andriamarovololona, M.M., Hockley, N., (2008) The importance of taboos and social norms to conservation in Madagascar. Conservation Biology 22, 976-986. 


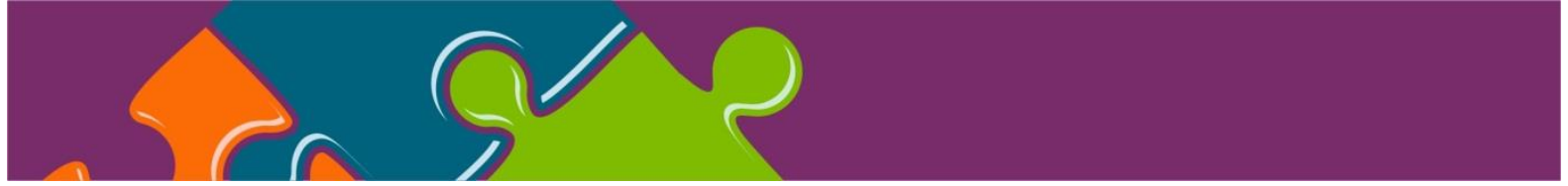

Mukamuri, B. B, Manjengwa, J. M. and Anstey, S. (eds) (2009) Beyond Proprietorship: Murphree's Laws on Community-Based Natural Resource Management in Southern Africa (Harare: Weaver Press/Ottawa: International Development Research Centre)

Murombedzi, J. (2001) 'Why wildlife conservation has not economically benefited communities in Africa', in D. Hulme and M. Murphree (eds) African Wildlife and Livelihoods (Oxford: James Currey), pp. 208-26

Murphree, M. (2001) Community, Council and Client. A case study in ecotourism development from Mahenye, Zimbabwe. in D. Hulme and M. Murphree (eds) African Wildlife and Livelihoods (Oxford: James Currey),

Murphree, M. (2005) Congruent Objectives, Competing Interests, and Strategic Compromise: Concept and Process in the Evolution of Zimbabwe's CAMPFIRE, 19841996. in J.P. Brosius, A.L. Tsing, and C. Zerner, (eds.) Communities and Conservation. Histories and Politics of Community-Based Natural Resource Management (Walnut Creek, CA: Altamira) pp. 105-147.

Neumann, R. P. (1998) Imposing Wilderness: Struggles over Livelihood and Nature Preservation in Africa (Berkeley, CA: University of California Press)

Neumann, R. P. (2001) 'Disciplining peasants in Tanzania: From state violence to selfsurveillance in wildlife conservation', in N. L. Peluso and M. Watts (eds) Violent Environments (Ithaca/London: Cornell University Press), pp. 305-27

Neumann, R. P. (2004) 'Moral and discursive geographies in the war for biodiversity in Africa', Political Geography, 23: 813-37

Newmark, W., D., Hough, J., L. , (2000) Conserving Wildlife in Africa: Integrated Conservation and Development Projects and Beyond. BioScience 50, 585-592.

Norgrove, L. And D. Hulme (2006) 'Confronting Conservation at Mount Elgon, Uganda' Development and Change, 37(5): 1093-1116

Norton-Griffiths, M., Southey, C., (1995) The opportunity costs of biodiversity conservation in Kenya. Ecological Economics 12.

Oates, J. F. (1999) Myth and Reality in the Rainforest: How Conservation Strategies Are Failing West Africa (Berkeley: University of California Press)

Oldfield, S. (ed.) (2003) The Trade in Wildlife: Regulation for Conservation (London: Earthscan)

Ostrom, E. (2010) Beyond Markets and States: Polycentric Governance of Complex Economic Systems. American Economic Review 100 (June 2010): 641-672.

Ostrom, E. (2000) 'Collective Action and the Evolution of Social Norms' Journal of Economic Perspectives, 14 (3): 137-158.

Ostrom, E., Burger, J., Field, C.B., Norgaard, R.B., Policansky, D., (1999) Revisiting the commons: local lessons, global challenges. Science 284, 278-282.

Peluso, N. L. (1993) 'Coercing conservation?: The politics of state resource control', Global Environmental Change, 3(2): 199-218

Ramutsindela, M. (2007) Transfrontier Conservation in Africa: At the Confluence of Capital, Politics and Nature (Wallingford: CABI)

Reeve, R. and Ellis, S. (1995) 'An insider's account of the South African security force's role in the ivory trade', Journal of Contemporary African Studies, 13: 222-43

Ribot, J. C. (2004) Waiting for Democracy: The Politics of Choice in Natural Resource Decentralisation (Washington DC: World Resources Institute)

Robbins, P., McSweeney, K., Chhangani, A. K. and Rice, J. L. (2009) 'Conservation as it is: Illicit resource use in a wildlife reserve in India', Human Ecology, 37(5): 559-75

Roe, D. et al (2010) Conservation and human rights: the need for international standards. Policy Briefing (London: IIED)

Roe, D. and J. Elliot (eds) (2010) The Earthscan Reader in Poverty and Conservation (London: Earthscan)

Roe, D. (2008a) Trading Nature: A Report with Case Studies, on the Contribution of Wildlife Trade Management to Sustainable Livelihoods and the Millennium Development Goals (Cambridge: TRAFFIC International and WWF International) 
